IZA DP No. 10190

Business Ethics in Organizations: An Experimental Examination of Whistleblowing and Personality

Jenny Bartuli

Behnud Mir Djawadi

René Fahr

September 2016 


\title{
Business Ethics in Organizations: An Experimental Examination of Whistleblowing and Personality
}

\author{
Jenny Bartuli \\ Continental ContiTech AG
}
Behnud Mir Djawadi
University of Paderborn

\author{
René Fahr \\ University of Paderborn \\ and IZA
}

\section{Discussion Paper No. 10190 \\ September 2016}

\author{
IZA \\ P.O. Box 7240 \\ 53072 Bonn \\ Germany \\ Phone: +49-228-3894-0 \\ Fax: +49-228-3894-180 \\ E-mail: iza@iza.org
}

\begin{abstract}
Any opinions expressed here are those of the author(s) and not those of IZA. Research published in this series may include views on policy, but the institute itself takes no institutional policy positions. The IZA research network is committed to the IZA Guiding Principles of Research Integrity.

The Institute for the Study of Labor (IZA) in Bonn is a local and virtual international research center and a place of communication between science, politics and business. IZA is an independent nonprofit organization supported by Deutsche Post Foundation. The center is associated with the University of Bonn and offers a stimulating research environment through its international network, workshops and conferences, data service, project support, research visits and doctoral program. IZA engages in (i) original and internationally competitive research in all fields of labor economics, (ii) development of policy concepts, and (iii) dissemination of research results and concepts to the interested public.
\end{abstract}

IZA Discussion Papers often represent preliminary work and are circulated to encourage discussion. Citation of such a paper should account for its provisional character. A revised version may be available directly from the author. 
IZA Discussion Paper No. 10190

September 2016

\section{ABSTRACT \\ Business Ethics in Organizations: An Experimental Examination of Whistleblowing and Personality}

The present paper suggests an innovative experimental design to study the nature and occurrence of whistleblowing in an employee-organization context. In particular, we aim at identifying whether student subjects in the role of employees are willing to blow the whistle on their managers' decisions to withhold money that is destined for a charitable purpose. Since the sole act of reporting leads to negative financial consequences for both players, the employee faces a conflict between ethical considerations and monetary interests. Of the 111 employee-manager pairings, 88 managers misappropriate the donation funds and 33 employees blow the whistle on their managers' fraudulent behaviors. We use different scales of the HEXACO and the DOSPERT personality inventory to link measures of personality traits to actual behavior which enables us to identify specific characteristics that distinguish whistleblowers from silent observers. We find that the Honesty-Humility factor scale is a strong predictor for whistleblowing. Further, employees who are more altruistic and more aware of ethical issues are more likely to refrain from supporting fraud and report wrongdoing. With the foci on research exploring individual and situational antecedents of whistleblowing, our experimental design offers researchers a new approach to studying organizational behavior of ethical scope under controlled and incentive-compatible conditions.

JEL Classification: C91, I11

Keywords: whistleblowing, fraud, organizational wrongdoing, social norms, experimental economics, laboratory experiment

Corresponding author:

Behnud Mir Djawadi

Department of Management

University of Paderborn

Warburger Str. 100

D-33098 Paderborn

Germany

E-mail: behnud.mir.djawadi@uni-paderborn.de 


\section{Introduction}

Business ethics receive increasing importance in organizations and include ethical values such as honesty, respect and obeying the laws and rules. Consider an employee faced with the dilemma to report a serious wrongdoing by his department head to high ranked superiors, not knowing how this will affect his career. It is in the nature of whistleblowing ${ }^{1}$ and the hidden nature of the preceding wrongdoing that any personal dispositions of the whistleblower and wrongdoer as well as the situational context leading to fraud and whistleblowing, are hardly if at all - observable by a researcher. This is even more true in situations where organizational insiders decide against blowing the whistle and making the case public.

In the present paper, we suggest a framework which endogenizes fraudulent acts and the decision to blow the whistle in an employee-organization context. Our experimental design allows researchers to analyze situational as well as personal correlates for the inclination to blow the whistle.

We see this research of major importance for businesses, as fraud in organizations, mostly in the form of asset misappropriations, corruption, embezzlement and financial statement fraud, is far from being solved and mitigated. According to the recent report by the Association of Certified Fraud Examiners (ACFE), organizations lose on average 5\% of their revenues each year to fraud which translates to a potential projected global fraud loss of nearly $\$ 3.7$ trillion (Association of Certified Fraud Examiners 2014). Despite the promulgation of different regulations, federal sentencing guidelines and the Sarbanes-Oxley Act, in more than half of the cases, the final piece of information which leads to detection of wrongdoing, comes from tips of employees (Dyck et al. 2010, KPMG 2007, PricewaterhouseCoopers 2012, Transparency International 2010).

Consequently, it is not surprising that various public and private agencies promote whistleblowing as mandatory for corporate compliance and ethics agendas. However, to be or not to be a whistleblower is of considerable ethical complexity and personal significance (Hoffman and McNulty 2011). The question therefore arises as to how organizations must be

\footnotetext{
${ }^{1}$ We refer to Jubb (1999) for defining whistleblowing: Whistleblowing is a deliberate non-obligatory act of disclosure, which gets onto public record and is made by a person who has or had privileged access to data or information of an organization, about non-trivial illegality or other wrongdoing whether actual, suspected or anticipated which implicates and is under control of that organisation, to an external entity having potential to rectify the wrongdoing.
} 
shaped so that the ethical tension points, when it is permissible to blow the whistle and when it is a duty, becomes more salient and better resolved.

Identifying these determinants on the inclination to blow the whistle presents a significant challenge in the research community. Conducting surveys of actual whistleblowers elicits true information about personality and the situational context in which the employee reported wrongdoing. However, the lack of control groups disguises the true determinants and characteristics that whistleblowers have in common and which differentiate them from nonreporting observers in the same situation. Circumventing this methodological hurdle, a second approach is to use scenarios, interviews or survey-based methods to discover which employees are more likely to blow the whistle by expressing intentions to report wrongdoing in hypothetical situations. Recent meta-studies consistently reveal large differences between whistleblowing intention and actual whistleblowing; thus generalizing from intent to actual whistleblowing may not be a wise strategy (Mesmer-Magnus and Viswesvaran 2005).

The present paper suggests a new methodological approach to study the nature and occurrence of whistleblowing. We design an incentive-compatible economic laboratory experiment which exposes student participants to real organizational conditions and to the trade-off between ethical decision-making and monetary consequences. Specifically, in our experiment: a) students in the roles of a manager and an employee form a division and work as a team to receive their payoff; $b$ ) the manager can additionally embezzle money that is assigned to a real charity, and thus, this wrongdoing creates negative externalities to an innocent third party; c) there is a loyalty conflict for the employee to remain silent or to report the wrongdoing and face retaliation.

By transferring the key features of the typical employee-organization interactions into an equivalent simplified experimental setting, we are able to provide clean evidence on the inclination of whistleblowing on fraudulent behavior under real monetary incentives, while controlling for important organizational variables, such as supervisor support for whistleblowing, type and seriousness of wrongdoing and the threat of retaliation. We use several standardized personality questionnaires to link measures of personality traits to actual behavior which enables us to identify specific characteristics that distinguish whistleblowers from silent observers.

The remainder of the current study is structured as followed: In $\S 2$ we review the existing and related literature whose insights significantly shaped our experimental design. In $\S 3$ we describe our experimental design in more depth and provide information about the experimental 
procedure. In $\S 4$ we introduce and develop our behavioral hypotheses and present the results in $§ 5$. Finally, §6 concludes.

\section{Related and Existing Work}

The central debate on whistleblowing concerns how the employee should solve the moral conflict between the duty of loyalty towards the organization where one works and the right to political free speech (Hersh 2002, Lindblom 2007). Approaching this question from a normative perspective, De George $(2010)^{2}$ provides a succinct analysis of the condition under which external whistleblowing by employees can be considered either morally permissible or morally obligatory. However, his proposed set of normative criteria has been subject to major critique in light of empirical research and new whistleblowing legislation, arguing the criteria raised so high that many organizational wrongs would go unchallenged (Davis 1996, Hoffman and McNulty 2011, Hoffman and Schwartz 2015, Lindblom 2007). Consequently, much research has adopted a more descriptive view and has sought to identify the determinants of whistleblowing along the different constituents of the (non-)reporting process, e.g. how the employee develops intentions to blow the whistle (Dozier and Miceli 1985, Miceli and Near 1992) and how individual characteristics and situational factors affect the likelihood that the employee will report wrongdoing (Vadera et al. 2009, Dworkin and Baucus 1998, Cassematis and Wortley 2013, Mesmer-Magnus and Viswesvaran 2005, Miceli and Near 2002, Rothschild and Miethe 1999).

The empirical evidence that individual-level characteristics are associated with the decision to blow the whistle is rather inconsistent and inconclusive (Vadera et al. 2009). Near and Miceli (1996) find that whistleblowers tend to be male, older, and higher educated. Other studies included in the meta-study by Mesmer-Magnus and Viswesvaran (2005) suggest that female employees are more likely to blow the whistle, while Cassematis and Wortley (2013) could not identify any sociodemographic characteristics that distinguish whistleblowers from silent observers. Similarly, findings of other personal characteristics, such as age, tenure, job satisfaction, job performance and education on whistleblowing behavior are rather mixed and often contradictory (Vadera et al. 2009, Near and Miceli 1996, Mesmer-Magnus and Viswesvaran 2005, Dworkin and Baucus 1998, Sims and Keenan 1998). Apart from strongly focusing on demographic factors, some previous research has examined distinct personality

\footnotetext{
${ }^{2}$ De George's discussion about the morality of whistleblowing was first published in his textbook Business Ethics in 1986.
} 
traits, such as proactive behavior, positive affectivity, the Big Five and locus of control. While Miceli et al. (1991) do not find any correlation between locus of control and whistleblowing behavior, there is evidence that whistleblowers have higher levels of positive affectivity and more proactive personalities than silent observers (Jos et al. 1989, Miceli et al. 2001). Another recent study by Bjørkelo et al. (2010) finds that individuals scoring high in Extraversion and low in Agreeableness seem to be more prone to the decision to blow the whistle.

At first sight, situational characteristics, rather than personal characteristics, seem to be more appropriate in predicting whether employees will blow the whistle. For instance, studies provide evidence that higher seriousness of the wrongdoing (Cassematis and Wortley 2013, King, III. 1997, Miceli and Near 1992, Near and Miceli 1985, Rothschild and Miethe 1999) and a more pronounced ethical climate in the organization (Near et al. 1993, Oh and Teo 2010, Sims and Keenan 1998) increases the likelihood for whistleblowing. Fear of retaliation is found to lower the willingness to report wrongdoing (Cassematis and Wortley 2013, Miceli and Near 1984). However, the meta-study by Mesmer-Magnus and Viswesvaran (2005) expresses doubt upon the consistency of these results. When differentiating between whistleblowers' intent and actual whistleblowing, only a more pronounced organizational ethical climate has a small positive effect on whistleblowing behavior.

Because organizational fraud and the act of whistleblowing are hardly observable by the researcher, all mentioned studies rely heavily on the methodology of surveys, scenarios, selfreports and non-validated measures of personality. Since whistleblowing involves ethical issues, it is very likely that the results are blurred by self-selection of the respondents, social desirability and self-reporting bias (Hersh 2002, Miceli and Near 1992). Equivalently, surveybased and scenario-based approaches on whistleblowing intentions do not easily translate into reliable conclusions about actual whistleblowing (Hersh 2002, Mesmer-Magnus and Viswesvaran 2005). To this end, we design a laboratory experiment which consists of a general framework that allows for replication and the investigation of real behavior and revealed preferences under controlled conditions and salient incentives. We argue that studying whistleblowing behavior experimentally requires certain design features: a) an employeeorganization interaction in which the potential whistleblower is part of the organization and observes the organizational wrongdoing as part of his regular job; b) a third party suffers from the observed wrongdoing; c) there is a loyalty conflict for the potential whistleblower between reporting wrongdoing, which leads to own monetary costs, or remaining silent. Related experiments in the domain of business ethics systematically investigate truth-telling in the laboratory (see for example: Cohn et al. 2014, Fischbacher and Föllmi-Heusi 2013, Gneezy 
2005, Mazar et al. 2008). Participants cheat for their own monetary advantage, but far less than predicted by standard economic theory. It is therefore argued that people have different levels of lying costs, which prevent them from being completely dishonest. However, this research cannot be applied directly to whistleblowing since in these experiments, there are no negative externalities to a third party and the outcome of dishonesty does not depend on the cooperation of any other partner. These situations are considered in experiments about (petty) corruption. The usual set-up consists of one player offering a bribe to a second player, who accepts or declines the offer with negative monetary consequences to a third party (Abbink et al. 2002, Barr and Serra 2009, Serra and Wantchekon 2012). The difference to our design lies in the structure of the game. Corruption experiments either do not account for repeated organizational interactions and/or do not model the consequences associated with whistleblowing which immediately terminates the interaction for all future periods. If the bribee declines the offer in one period of the corruption experiment, the briber can again offer the bribe to the same partner in the next period. Most closely related to a whistleblowing setting is the experimental study by Reuben and Stephenson (2013) which focuses on the willingness to report lies of other members of the organization and the consequences thereof. However, there are no interactions among the organizational members, and unethical behavior - in form of lies - does not harm any organizational member or third party. Other experiments, particularly in the context of public good or dictator games, reveal that people have altruistic motives and punish others who violate the social norm, even if punishment is costly (Fehr and Fischbacher 2004, Fehr and Gächter 2002, Fehr et al. 2002). However, in these experiments, people mostly punish others to enforce cooperation in the next periods. In our setting, no interaction and thus no cooperation is possible after reporting wrongdoing so that motives observed in public good games are likely to be different from motives in the whistleblowing context. Further, experimental work exists about the effectiveness of different leniency policies and reward schemes for whistleblowers (Apesteguia et al. 2007, Bigoni et al. 2008, Hinloopen and Soetevent 2008). In these settings, participants can form cartels and agree upon market prices. Different leniency policies for whistleblowers are examined as to which policy is most effective in increasing antitrust and deterring cartel formation in the first place. We see several differences compared to our whistleblowing design: in cartel experiments, there is neither a loyalty conflict nor negative externalities to a third party, and under certain conditions, cartel members can even increase their payoffs by blowing the whistle. In our experiment, employees always lose money if they blow the whistle, so that ethical concerns override any monetary endeavor. 


\section{Whistleblowing in Organizations: A Laboratory Experiment}

\section{Experimental Design}

Our experimental design simulates a simple employee-organization interaction. Most experimental economists rely on context-free framing and thereby attempt to avoid all connotations caused by the choice of words that might affect individuals' decisions. However, if the major interest is to transfer real-life situations to the laboratory and to investigate the underlying behavioral preferences, it is argued that the use of neutral framing may distort the interpretability of the experimental results (Abbink and Hennig-Schmidt 2006, Davis and Holt 1993, Eckel and Grossman 1996). We therefore frame our experiment in an organizational context. The course of events is displayed in Figure 1. Participating student subjects are told that they work in a division of a large company. The headquarters of the company is located in Germany, but the division is in South Africa. The division consists of exactly two members, a manager and a subordinate employee. An estimation task determines which role one subject is going to play; in particular, subjects who perform above average are assigned the role of the manager, while the subjects who perform below average become employees. Using this allocation process, we assure that subjects deserve their job position by performance rather than being randomly assigned by the experimenter. We then pair one manager with one employee; each matched manager-employee pair works at most 16 periods together. The pair jointly works on a real effort task to generate its income. The major advantage of real effort tasks in laboratory experiments is the external validity (Gill and Prowse 2012), since exerting an effort in the laboratory comes closer to real world situations where effort leads to payoff. Furthermore, individuals tend to spend a payoff that they have earned themselves more thoughtfully than a payoff they have received without any effort (Arkes et al. 1994, Boylan and Sprinkle 2001, Cherry et al. 2002). The task consists of counting the occurrence of the digit " 7 " out of four matrices of randomly drawn numbers ${ }^{3}$. The manager and the employee each work separately on two matrices and the result of their counting is aggregated. The players have as much time as they need to make sure that each division receives their payoffs with almost certainty. The task is successfully completed if the overall reported occurrence of the digit "7" does not deviate by more than $+/-4$ from the true occurrence of the digit " 7 " in the four matrices. After the task is completed, both members receive feedback about the overall team performance. Having accomplished this task successfully, the team is granted a payoff of 10 monetary units of the experimental currency Taler. Out of these 10 Taler, the manager in his executive position

\footnotetext{
${ }^{3}$ A screenshot of the counting task is provided in Appendix A.
} 
receives a payoff of 6 Taler, and the employee a payoff of 4 Taler, respectively. In the event of failure, the players receive no payoff. This task is repeated for five periods to develop an organizational climate and a stable manager-employee relationship. From period six onwards, the manager receives from the headquarters an additional duty to pass on a fixed amount of 10 Taler to a charity. This new budget corresponds to one period team production and is given in each of the remaining periods six to sixteen. In all of these periods, this budget is entirely independent of the division members' incomes so that no money of the players is taken for any donations. The charity is a real NGO student organization ${ }^{4}$ and renowned to the participants for its social work in South Africa, devoted to children who have lost their parents to HIV. We chose this charity for several purposes: firstly, we expose our subjects to real life aspects of organizational work, as it is common in reality that a company supports a charity that does social work in the same community. Secondly, we introduce a real third party which is negatively affected if wrongdoing occurs. Several economic experiments showed that subject's preferences are better revealed if all the players and institutions are real rather than hypothetic (see for example Eckel and Grossman 1996). Thirdly, it is a charity project in which even small amounts of money are of great help for the people, so that any wrongdoing has a severe impact on the donation budget. Subjects are told that the headquarters at no time can control whether the manager really passed on the donation money so that the manager's embezzlement is only detected if the employee reports on the manager's wrongdoing by blowing the whistle. In each of the periods six to sixteen, the manager decides between forwarding the full amount of 10 Taler to the charity project, as expected by the headquarters, or embezzle the money by keeping the entire donation budget in the division of the company. After the manager has made his choice, the employee is informed about the decision. In the case that the manager decides to pass on the assigned money, the 10 Taler are donated to the charity project and the experiment continues with the next period. In the next period after the completion of the team task, the manager again has to decide about the use of the new donation budget. In contrast, if the manager opts to keep the 10 Taler in the division of the company, the employee can decide whether he accepts the manager's decision or whether he reports the manager's decision to the headquarters. If the employee decides to accept the manager's decision, the 10 Taler will be divided between the manager and the employee exactly as their usual payoff from the team task: the manager receives 6 Taler and the employee the remaining 4 Taler. Thus, if the team task is accomplished successfully and the manager opts to keep the donation budget in the

\footnotetext{
${ }^{4}$ The charity is called GoAhead!. More detailed information can be found in Appendix B and on the charity's website: http://www.goahead-organisation.de/index_eng.html
} 
division and the employee accepts, in total, the manager's payoff in that period adds up to 12 Taler and the employee earns 8 Taler. Dividing the money between the manager and the employee in that manner is meant to increase the loyalty conflict of the employee and avoid whistleblowing that is solely driven by motives of inequality aversion. After the manager has embezzled the money once, the manager's decision to embezzle the money is automatically implemented in the following periods and the employee again is given the choice to accept the decision or report to the headquarters. Whistleblowing, just as other real-world activities that have some social dilemma aspects, is typically not a one-time encounters (Heyes and Kapur 2009, Levitt and List 2007, Rothschild and Miethe 1999). Therefore, the potential whistleblower needs to be granted more than one period for his decision whether to report or not. Similarly, in the real world, an employee does not have a definite period of time in which he can report the wrongdoing. Another aspect adding reality to the experiment is the employee's involvement. Since both players form a division, the employee who might blow the whistle is no third-party, but is deeply involved in all actions. In the experiment, the employee is the only person being informed about the manager's wrongdoing. Thereby, the employee as a potential whistleblower has inside information that an external agent is not able to observe. Even though the manager performs the activity in question, the potential whistleblower does not only passively observe the wrongdoing, but, by being an active part of the division and financially benefiting from the manager's embezzling, he or she is an accomplice. If the manager chooses to keep the 10 Taler and the employee decides to report the manager's decision to the headquarters, the team faces three consequences: First, the money that the manager has withheld in the current period is claimed back and the money of this period and the budgets of all future periods are automatically donated to the charity project. Second, the headquarters dissolve the division and both, the manager and the employee have to work individually in all future periods. This represents the consequences in the real world, since after an employee reports on his manager, this division will not be able to work effectively any longer. Consequently, each player has to count the occurrence of the digit "7" individually and only the individual result from the two matrices now counts for successfully solving the task. Third, the individual players will receive a reduced payoff as a result of the detection. To introduce retaliation for the whistleblower, the employee's payoff for successfully accomplishing the task will be reduced from previously 4 to 3 Taler. Similarly, to account for sanctions, the manager's payoff for the task in all subsequent periods decreases from previously 6 to 5 Taler. Congruent with existing whistleblowing research, the second focus of our investigation lies on the distinct personality of the employees who blow the whistle or remain silent. Accordingly, standardized 
questionnaires at the end of the experiment are used to elicit these personality characteristics along with questions on the socio-economic background of the participants, such as age, gender and general attitude towards donating money. ${ }^{5}$

Figure 1: Experimental design of one manager-employee pair

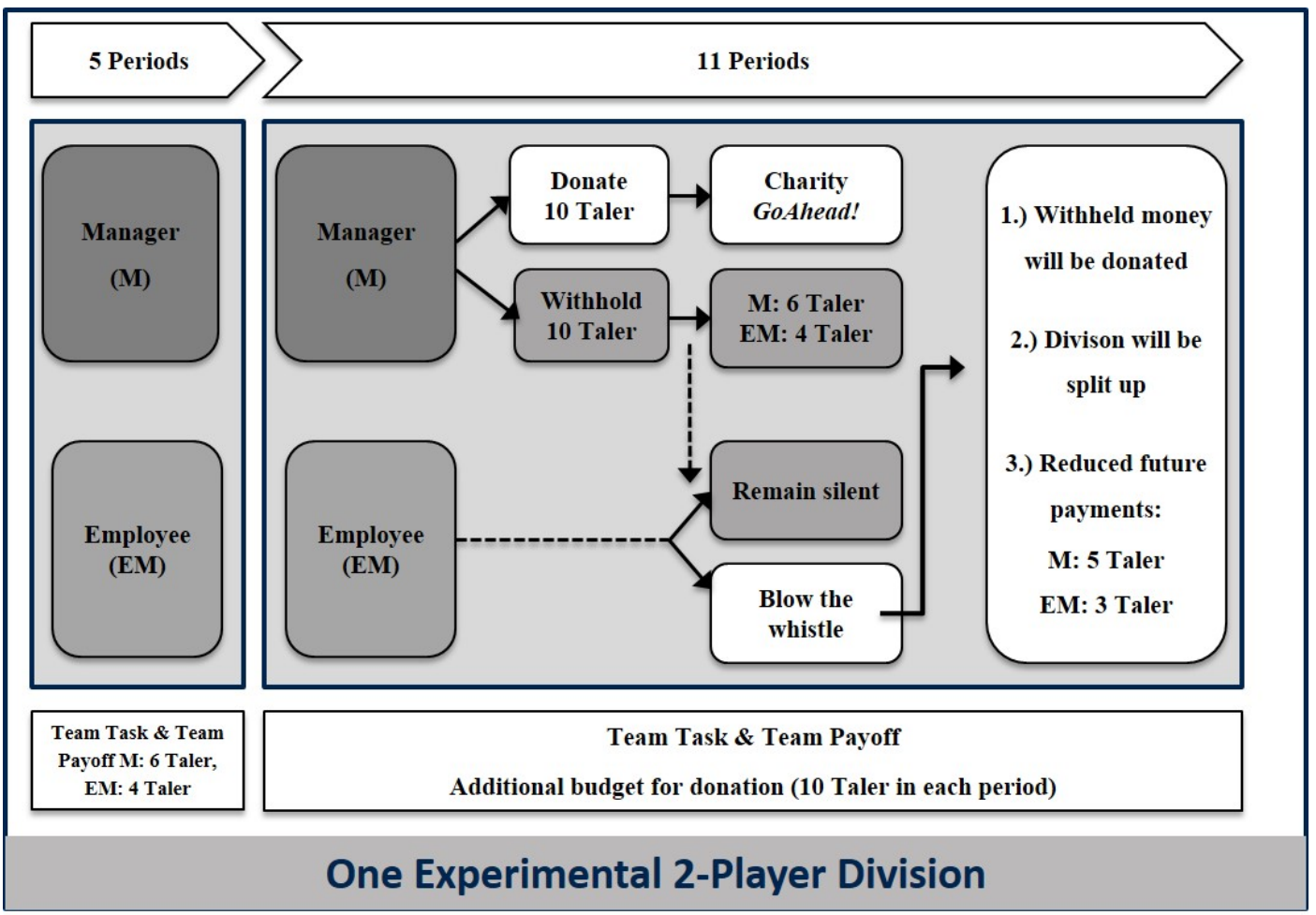

\section{Experimental Procedure}

The experiment was conducted at the Business and Economic Research Laboratory (BaERLab) in May 2012 and in April 2013 at the University of Paderborn, Germany. Subjects were recruited by the online recruiting system ORSEE (Greiner 2015) from a pool of approx. 2,200 voluntary students of the University of Paderborn from different fields of study, who are enrolled as prospective participants in economic experiments. We ran eight sessions with a total of 222 participants. Each subject was allowed to take part in only one session. On average, 28 subjects participated in each session. The experiment was computerized and conducted using the software z-Tree (Fischbacher 2007). As soon as the subjects arrived at the BaER-Lab, they were asked to randomly draw a number from a box and were told to sit down at the assigned computer workplace in a cubicle detached from each other, thus ensuring complete anonymity. In each session, the subjects received the same introductory talk and were told not to

\footnotetext{
${ }^{5}$ Note that participants also answered additional questions. However, these questionnaires were irrelevant for the current study.
} 
communicate during the complete session. Then, the written instructions were handed out and the subjects had fifteen minutes time to read them and ask questions in private to clarify any misunderstandings. The detailed instructions of our experiment can be found in Appendix B. In the instructions, subjects were completely informed about the course of events. Thus, all subjects knew beforehand about the structure of the experiment in which the first five periods only contained the team task, followed by introducing the additional donation budget in the remaining periods six to sixteen. Subjects also knew about all possible choices and consequences of donating or embezzling the money as well as remaining silent or blowing the whistle on the manager's action. Lastly, subjects were given information about the charity and the concrete donation project which we retrieved from the charity's website. At the start of the experiment, a simple estimation task decided about the role allocation. We prepared a jar filled with marbles and participants had to estimate the true number of marbles. The one half of participants, which was closest to the real number of marbles was assigned the role of the manager, while the other half was attributed the role of the employee. The participants kept their specific roles throughout the whole experiment. We randomly divided the participants into teams of two, consisting of exactly one manager and one employee who stayed together either until the end of the experiment or until the division was dissolved due to the employee's reporting of the manager's wrongdoing. The allocation to teams was anonymous and the participants had no information about the identity of their division member. After all periods of the experiment were played, subjects got to know the total sum of money that was donated in the session. We solely disclosed only aggregated information to the subjects so that nobody was able to trace the actions and decisions of the single divisions. Subsequently, participants were asked to fill out several standardized personality questionnaires and remain in their seats until their cabin number was called up to receive their final payoff. Each session lasted approximately 120 minutes and the participants were paid their total earnings anonymously in cash, at a conversion rate of one Euro for 8 Taler. Additionally, the participants were granted a show-up fee of EUR 2.50. Subjects earned on average EUR 15.48 which corresponds to roughly USD 21 at that time. We published the transfer confirmations of each of the session donations on the website of the BaER-Lab ${ }^{6}$ within a week after the experiment, so that participants were able to assure themselves that the total sum of the donation in the session had actually been transferred to the charity.

\footnotetext{
${ }^{6}$ http://www.baer-lab.org
} 


\section{Hypotheses}

We are interested in the behavior of the employee and ask to which extent the observed behavior can be explained by personal characteristics. According to the standard economic theory, both division members, the manager and the employee, are fully rational payoff maximizers. Thus, decisions are simple cost-benefit calculations and individuals will always choose the alternative that maximizes their own monetary payoff. Both the manager and the employee benefit monetarily from keeping the donation budget in their division. The employee observing the wrongdoing does not personally profit from the act of whistleblowing, thus, in the absence of other-regarding preferences, the employee will always refrain from blowing the whistle. Anticipating this behavior, the manager will always embezzle the money.

However, a large body of empirical field and experimental studies have accumulated evidence that individuals are not completely selfish and rational payoff maximizers, but rather norms of equity and fairness play an important role (see for example: Andreoni and Miller 2002, Bolton and Ockenfels 2000, Fehr and Schmidt 1999). Evidence from experiments on unethical behavior like deception, lying and cheating (e.g. Abeler et al. 2014, Fischbacher and FöllmiHeusi 2013, Gino et al. 2009, Gino et al. 2013, Gneezy 2005, Mazar et al. 2008) suggests that individuals attach importance to moral concerns, consider ethical reasoning and endure negative utility from being dishonest, even if unethical actions are unobserved. Even though it would be payoff maximizing for the employee to remain silent, it can be expected that a significant share of employees will blow the whistle on managers who embezzle the money. We therefore derive the following behavioral hypothesis:

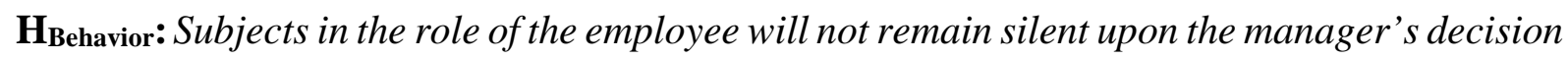
to embezzle the donation, and whistleblowing will occur.

We apply validated measures of personality to investigate the extent to which observed behavior is the result of the employee's personal characteristics. We decided for two scales of the so called $\mathrm{HEXACO}^{7}$ model (Ashton and Lee 2007, Ashton et al. 2014): Honesty-Humility and Altruism. The HEXACO model represents - like the Big-Five model (Norman 1963, Costa and McCrae 1995, McCrae and Costa 1987) - a lexical approach to structuring personality characteristics and has been extensively used for research in personality psychology as well as

\footnotetext{
${ }^{7}$ HEXACO: Honesty-Humility (H), Emotionality (E), eXtraversion (X), Agreeableness (A), Conscientiousness (C) and Openness to Experience (O)
} 
in industrial and organizational psychology. Particularly, the dimension of Honesty-Humility, which is described by aspects of honesty, sincerity, fairmindedness, greed, deceit and boastfulness (Lee and Ashton 2004, Ashton and Lee 2008a), has been empirically shown to be a vital predictor for a whole host of criteria with ethical context, such as counterproductive behavior at the workplace (Lee et al. 2005, Zettler and Hilbig 2010), unethical business decisions (Ashton and Lee 2008b) and criminal behavior (Rolison et al. 2013). Specifically, individuals scoring low in this domain are characterized by manipulating others, committing fraud and acting largely on monetary motives. Given this profile, we expect low-scoring employees to favor circumstances which yield possibilities to gain money by committing fraud; these employees thus abstain from reporting wrongdoing. Conversely, employees scoring high in Honesty-Humility are expected to avoid fraud and refrain from taking advantage of others, and therefore blow the whistle on the manager's wrongdoing. Hence, we state the following hypothesis:

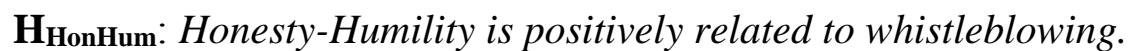

According to Levine's Altruism Theory (1998) and as shown by research on social preferences, individuals do not solely care about their own monetary payoff, but also about their counterpart's monetary payoff. Since the employee's decision to remain silent would reduce the welfare of others (the recipients of the donation), a more altruistic subject will be more likely to blow the whistle. The act of blowing the whistle meets the three criteria by Leeds (1963) for defining behavior as being altruistic: First, whistleblowing is not directed as selfgain; second, it is the individual's voluntary decision, and third, it results in a good cause. An employee's personality trait Altruism is measured by the HEXACO scale of the same name. This scale assesses the personal tendency to be sympathetic and softhearted toward others. Individuals scoring high in this personality trait tend to be interpersonally warm and empathic. High scorers avoid causing harm and react with generosity toward those who are weak or in need of help. In contrast, individuals who score low in Altruism are more likely to hurt others and can be described as rather hard-hearted. Thus, we hypothesize:

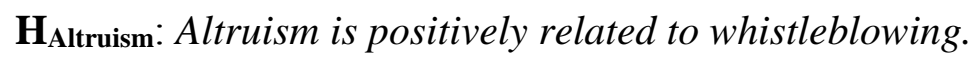

According to the prosocial behavior model (Brief and Motowidlo 1986), it can be assumed that individuals with strong prosocial tendencies, such as moral reasoning and ethical awareness, 
will be less likely to act unethically and thus are more likely, as an employee, to blow the whistle (Dozier and Miceli 1985). Research on prosocial behavior suggests that individuals with a strong prosocial attitude have higher standards of social responsibility, justice and moral reasoning (Brief and Motowidlo 1986, Kohlberg 1969). In our experimental study, the subjects' prosocial tendencies are measured on the basis of the Domain-Specific Risk-Taking (DOSPERT) scale (Weber et al. 2002). The domain Ethical out of the DOSPERT scale allows examining the individual's attitude toward ethical decision-making under risk and is therefore used as measure for attitudes towards prosocial behavior. Subjects scoring high in the domain Ethical are considered to have high ethical awareness and a strong attitude toward ethical decision-making. We expect employees scoring low on this scale to be more likely to remain silent. In contrast, high-scoring individuals in the scale Ethical are considered to be more likely to blow the whistle.

HProsocial: Prosocial tendencies based on attitudes toward ethical decision-making are positively related to whistleblowing.

\section{Results}

\subsection{Descriptive Statistics}

Table 1 summarizes the characteristics of our subjects and their behavior in the experiment. Our student sample consists of 222 subjects in total (111 managers and 111 employees) from different fields of studies. The student participants in the role of the employee are on average 23 years old, largely female and have donated at least once in their life to a real charity. In the eight sessions, $€ 98$ (= USD 132) on average were donated to the charity we used in the experiment. ${ }^{8}$ Looking at the first five periods in which the subjects played as a division and were paid under the team compensation scheme, it can be observed that all divisions solved the team task in each period correctly. All subjects stated in the subsequent questionnaire that they were satisfied with their own and the division partner's performance in the task. This assures that no risk considerations about failing the team task or committing fraud to compensate forgone payoffs might have driven the subject's decisions.

\footnotetext{
${ }^{8}$ The total payoff of all subjects in one session was on average $€ 430(\approx$ USD 578). The maximum amount that could be donated over all eight sessions was $€ 1526.50(\approx$ USD 2052$)$.
} 
Table 1: Summary statistics of the student subjects' demographic characteristics and behavior

\begin{tabular}{|l|cc|}
\hline \multicolumn{2}{|c|}{ Employees } \\
& \multicolumn{2}{|c|}{} \\
& $\begin{array}{c}\text { Mean } \\
(\%)\end{array}$ & $\mathrm{N}$ \\
& 23.26 & 111 \\
Age & & \\
Gender & 63.96 & 71 \\
Female & 36.04 & 40 \\
Male & & \\
Field of Studies & 33.33 & 37 \\
Business Administration \& Economics & 17.12 & 19 \\
Natural Sciences & 49.55 & 55 \\
Culture Sciences & & \\
\hline Donation Experience outside the Lab & 20.72 & 23 \\
Never ever donated to a charity & 68.47 & 76 \\
Rarely donating to a charity & 10.81 \\
Regularly donating to a charity & & 12 \\
\hline Observed behavior in experiment & 20.72 & 23 \\
No opportunity to blow the whistle & 9.01 & 10 \\
Blew the whistle immediately & 20.72 & 23 \\
First accepted, then blew the whistle & 49.55 & 55 \\
Remained silent & & 111 \\
\hline Total & & \\
\hline
\end{tabular}

In each of the periods six to sixteen, the respective manager had the choice between donating or embezzling the additional monetary budget, and subsequently, in case of embezzlement, the subject in the role of the respective employee had the choice between blowing the whistle or remaining silent. The different behavioral patterns and the timing of the embezzlement and whistleblowing actions are summarized in Table 1 and Figure 2. In 23 out of the 111 divisions, the managers always decided to donate and never embezzled the money. Consequently, in these divisions the employees never had to make the decision between remaining silent or blowing the whistle. However, 88 managers $(79.28 \%$ ) decided to embezzle the money at least once and roughly one third of them embezzled the money immediately from period six onwards. Subsequently, in total, 33 employees $(37.50 \%)$ blew the whistle upon the managers' wrongdoing. Ten employees decided to report their respective manager immediately after the first embezzlement, whereas 23 employees blew the whistle after some subsequent periods, in which the money was embezzled and divided up in the division. Roughly $63 \%$ of employees remained silent upon the manager's fraudulent decisions. 


\subsection{Behavioral Hypothesis}

To test our behavioral hypothesis, we examine the behavioral patterns of the employees. From the standard economic theory, we can derive that in cases, in which the managers embezzle the donation budget, all employees refrain from blowing the whistle, as this is the only moneymaximizing strategy. However, we can clearly reject this conjecture. The Binomial-Test calculation reveals that, under the assumption of solely observing non-whistleblowing, the probability of observing 33 employees who blow the whistle out of a sample of 88 divisions is virtually zero (Binomial Test: $\operatorname{Pr}($ all employees will remain silent $\mid 55$ non-whistleblowing incidence out of 88 fraud decisions): $\mathrm{p}<0.00000001$ ). Consequently, we find support for our behavioral hypotheses HBehavior, indicating that a significant share of subjects in the role of employees set ethical priorities over monetary concerns and do act ethically.

Figure 2: Cumulative distribution of all observed embezzlement and whistleblowing behavior over time

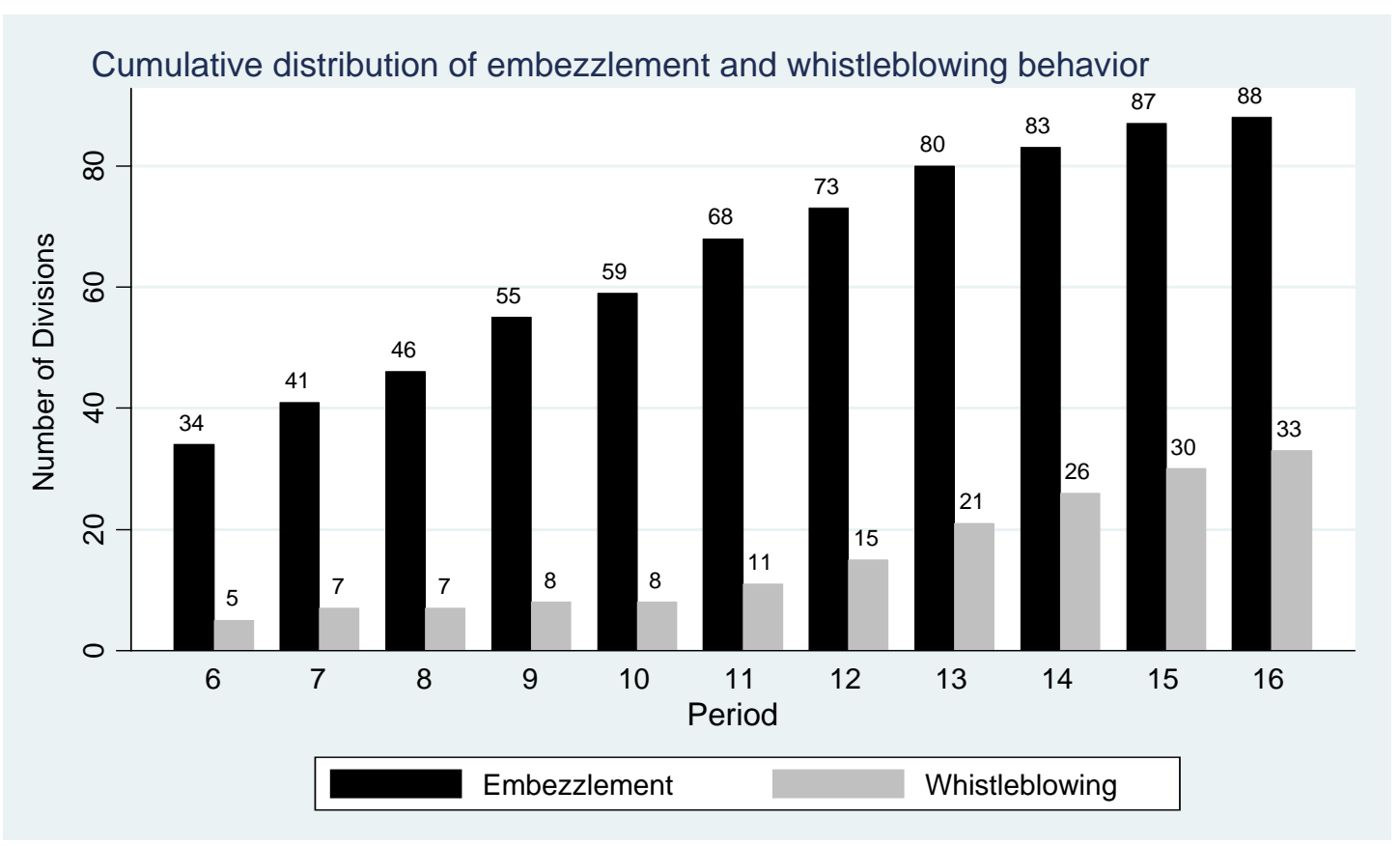

However, we find that the period, in which the manager embezzled the additional donation budget the first time, affects the employee's inclination to blow the whistle. Table 2 shows the reaction of the respective employees for each of those periods. For example, when the donation budget was already embezzled in period six for the first time, we see that out of 34 divisions, 15 employees in total blow the whistle in the periods six, eleven, twelve, thirteen and fourteen. Employees of 19 divisions remain silent upon their manager's fraudulent decisions. Comparing the (non-) whistleblowing actions in the periods 6 to 10 versus 11 to 16 we observe that those managers who commit fraud in later periods have a significantly higher chance that the 
employee will not blow the whistle, compared to those managers who embezzle the donation budget already in early periods (Chi-Square Test: $\left.\chi^{2}(\mathrm{df}=1): 3.30 ; \mathrm{p}=0.069\right)$.

Table 2: Whistleblowing and non-whistleblowing actions conditional on the period, in which the donation budget was embezzled the first time (in absolute numbers)

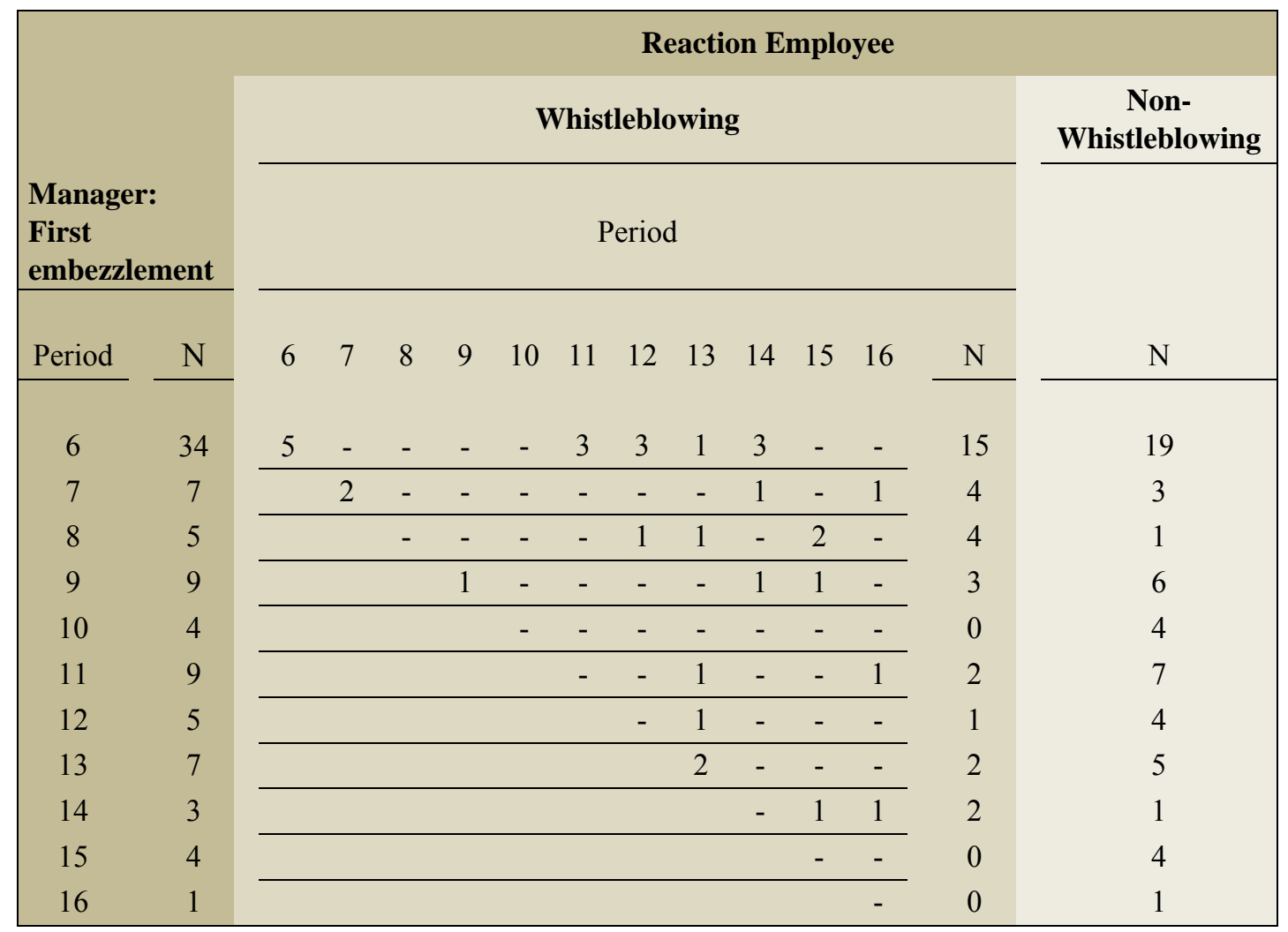

\subsection{The relationship between personality characteristics and observed behavior}

The HEXACO scales Honesty-Humility and Altruism were measured with the German version of the 60-item and 100-item HEXACO Personality Inventory-Revised (Ashton and Lee 2009). The HEXACO-60 encompasses 10 items for the Honesty-Humility, whereas the HEXACO100 version contains 4 items for the Altruism scale. In both inventories, respondents indicate to what extent they agree or disagree with a range of statements about themselves on a 5-point Likert scale. Sample items of Honesty-Humility include statements such as "If I knew that I could never get caught, I would be willing to steal a million dollars" or "I would never accept a bribe, even if it were very large". For our purposes, we further shortened the inventory of the Honesty-Humility questions to 8 items excluding 2 items about the sub-facet "modesty". The individuals' prosocial tendencies were measured by the DOSPERT scale Ethical ${ }^{9}$ (Weber et al. 2002), which assesses the risk perception of situational circumstances that contain ethical

\footnotetext{
${ }^{9}$ The items of the Honesty-Humility, the Altruism and the Ethical scales which we used in the post-experiment questionnaire can be seen in Appendix C.
} 
context. The scale consists of 6 items and respondents indicate how risky they perceive the consequences of unethical acts like "Not returning a wallet you found that contains $\$ 200$ " or "Taking some questionable deductions on your income tax return" being revealed on a 7-point Likert scale. The short scenarios described in the questionnaire resemble the situation of the manager-employee relationship in the experiment quite well and are therefore very suitable for assessing the employee's attitude towards ethical decision-making under risk. Table 3 shows the means and standard deviations of the different personality scales. As expected, employees, who blow the whistle in the experiment, display on average higher scores on all personality measures compared to non-whistleblowers. However, this difference is only statistically significant with regard to Honesty-Humility.

Table 3: Means and standard deviations of personality measures separated by employees who blew the whistle or remained silent

\begin{tabular}{|c|c|c|c|c|c|}
\hline \multirow[b]{2}{*}{ Measures } & \multicolumn{2}{|c|}{ Whistleblowers } & \multicolumn{2}{|c|}{ Non-Whistleblowers } & \multirow[t]{2}{*}{$\mathrm{M}-\mathrm{W}$ rank-sum test } \\
\hline & Mean & SD & Mean & SD & \\
\hline Honesty-Humility & 3.38 & 0.54 & 3.00 & 0.63 & $2.79^{* * *}$ \\
\hline Altruism & 3.77 & 0.43 & 3.61 & 0.57 & 1.41 \\
\hline Prosocial Attitude & 2.11 & 0.70 & 2.04 & 0.82 & 0.79 \\
\hline
\end{tabular}

Note: $\mathrm{N}=88$. Mann-Whitney rank-sum tests are used to compute differences in means. All tests are two-tailed, significance at the $1 \%$ level is denoted by $* * *$.

To test our hypotheses on personality, we use a binary probability model. Although our dataset has a panel structure, we decided for a cross-sectional logistic regression model, which allows including determinants that are constant over time for each individual, such as demographics and personality characteristics. The dependent variable in all three model specifications is whether the whistle was blown $(=1)$ or not $(=0)$ in interactions where the manager decided to embezzle the donation. We therefore consider 88 observations for the regression analysis. In the second and third model specification, we include controls for gender, general donation experience outside the laboratory, age, fields of study and number of terms. Table 4 reports the marginal effects of each coefficient, while robust standard errors are shown in parentheses. Consistent with our hypothesis HHonHum, we see a strong positive relationship between HonestyHumility and the inclination to blow the whistle. A one-unit increase in the Honesty-Humility scale increases the probability to blow the whistle by 37.2 and 45.1 percentage points, respectively. As shown in the third model specification, the relationship is mostly driven by the Honesty-Humility sub-facets of fairness and greed avoidance, which in particular examine the tendency to avoid corruption and to not merely act on monetary motives. In all specifications, 
the relationship between altruism and whistleblowing is qualitatively in line with the prediction

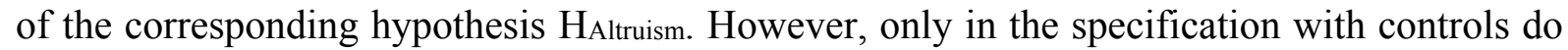
we find that an increase in altruism significantly increases the likelihood to blow the whistle. In all other specifications, the coefficient is lower in magnitude, resulting in insignificant effect sizes. These findings suggest that only a minority of whistleblowers tend to act mainly out of altruistic reasons. Table 1 shows a significant share of 10 out of 33 employees who blow the whistle immediately on the manager's first embezzling action.

Table 4: Binary logistic regressions correlating measures of personality and prosocial attitude with observed (non)-whistleblowing behavior of employees

\begin{tabular}{|c|c|c|c|}
\hline \multirow[t]{2}{*}{ Dependent Variable: } & \multicolumn{3}{|c|}{ Blowing the Whistle } \\
\hline & (1) & (2) & (3) \\
\hline Honesty-Humility & $\begin{array}{c}0.372^{* * *} \\
(0.130)\end{array}$ & $\begin{array}{c}0.451^{\text {*** }} \\
(0.137)\end{array}$ & \\
\hline Sincerity & & & $\begin{array}{c}0.0574 \\
(0.0739)\end{array}$ \\
\hline Fairness & & & $\begin{array}{l}0.245^{* *} \\
(0.102)\end{array}$ \\
\hline Greed & & & $\begin{array}{c}0.166^{*} \\
(0.0926)\end{array}$ \\
\hline Altruism & $\begin{array}{c}0.196 \\
(0.127)\end{array}$ & $\begin{array}{c}0.212^{*} \\
(0.123)\end{array}$ & $\begin{array}{c}0.180 \\
(0.124)\end{array}$ \\
\hline Prosocial Attitude & $\begin{array}{l}0.247^{* * *} \\
(0.0948)\end{array}$ & $\begin{array}{c}0.378^{* * *} \\
(0.135)\end{array}$ & $\begin{array}{l}0.414^{* *} \\
(0.161)\end{array}$ \\
\hline Embezzlement Period & $\begin{array}{l}-0.0329^{*} \\
(0.0198)\end{array}$ & $\begin{array}{l}-0.0287 \\
(0.0220)\end{array}$ & $\begin{array}{c}-0.0291 \\
(0.0215)\end{array}$ \\
\hline Controls & $\mathrm{NO}$ & YES & YES \\
\hline $\begin{array}{l}\text { Observations } \\
\text { Pseudo } \mathrm{R}^{2}\end{array}$ & $\begin{array}{c}88 \\
0.16\end{array}$ & $\begin{array}{c}88 \\
0.28\end{array}$ & $\begin{array}{c}88 \\
0.31\end{array}$ \\
\hline
\end{tabular}

Note: Marginal effects were calculated, robust standard errors are reported in parentheses. Model specifications (2) and (3) include controls for gender, donation preference outside the laboratory, age, field of studies and number of terms. Model specification (3) reports marginal effects of the sub-facets of the Honesty-Humility scale. Significance at the $1 \%, 5 \%$, and $10 \%$ level is denoted by $* * *, * *$ and $*$, respectively.

This behavior can be interpreted as purely altruistic, since blowing the whistle on the first fraudulent incident minimizes the future individual earnings of the employee. These employees also score the highest on the Altruism scale (mean $=3.9$, std. $=0.44$ ), thus strengthening the conjecture that more altruistic employees are also more likely to blow the whistle. On the other hand, the fact that, in most cases, employees accepted their managers' wrongdoing for some 
periods before they blew the whistle, supports the view that also motives other than altruistic ones affect the act of whistleblowing. This can also be documented by the Altruism scale, showing no differences in altruism between employees who blow the whistle with some delay compared to non-whistleblowers (M-W Test (two-sided): $\mathrm{z}=0.80, \mathrm{p}>0.1$ ). Turning to the last personality measure, we find that attitude towards prosocial behavior is significantly correlated with whistleblowing behavior. Specifically, in all three model specifications, the results support our hypothesis HProsocial which indicates that higher ethical awareness increases the probability to blow the whistle. Lastly, we turn to the timing of the first embezzlement action. Consistent with the findings in section 5.2., the later the manager embezzles the donation for the first time, the more likely it is that the employee will remain silent and not blow the whistle.

\section{Discussion and Conclusion}

The present study suggests an innovative experimental framework to study the nature and occurrence of whistleblowing in an employee-organization context. Student subjects in the role of the manager can commit fraud by embezzling money that is destined for a real charity for their own monetary gain, without fearing penalties from the organization. Detection is only possible, if the employee observing the manager's wrongdoing blows the whistle. Since the sole act of reporting leads to negative financial consequences for both division members, the decision to blow the whistle seems to be guided by ethical considerations that outweigh pure monetary interests. We collect data on 111 manager-employee pairings, where the vast majority of 88 managers misappropriate the donation funds at least once. Our first key result is that $38 \%$ of the employees who are engaged in a corrupt relationship with their managers blow the whistle and report the manager's wrongdoing. Relating to the behavioral ethics and lying literature, we explain this observed behavioral pattern through different levels of lying costs individuals have when deciding about choices of ethical scope. Our second behavioral finding concerns the timing of whistleblowing. In most of the whistleblowing cases, employees observe their manager's wrongdoing for some time and then blow the whistle. Consequently, managers who commit fraud in later periods have a higher chance of remaining undetected until the end of the experiment.

A second explanation for the observed behavior are individual differences in personality. We address the question of who blows the whistle, by eliciting personality characteristics with the Honesty-Humility and Altruism scale of the HEXACO model and attitudes towards prosocial behavior with the DOSPERT Ethical scale. We find that whistleblowers differ in their 
personality profile, compared to non-whistleblowers. First, we find a strong link between Honesty-Humility and whistleblowing behavior. In line with previous work in personal psychology, suggesting an association between Honesty-Humility and manipulating or cheating behavior, we provide first evidence that Honesty-Humility is also a considerable predictor for whistleblowing, which can be regarded as behavior of the positive ethical domain. Second, whistleblowers tend to be more altruistic than silent observers. However, as described in the analysis section, this relationship applies mainly to employees who blow the whistle immediately after the manager's first embezzlement action. These results reinforce previous research in the following way: altruistic concerns indeed lead to the decision to blow the whistle but this is not the only reason for whistleblowing (Dozier and Miceli 1985, Dasgupta and Kesharwani 2010). Rather, the majority of whistleblowers first benefit financially from the managers' fraudulent actions so that the observed behavior involves both selfish and altruistic motives on the part of the whistleblower. Third, we find a link between ethical judgment and organizational behavior. From the results of the Ethical scale, it becomes evident that those employees who are more aware of ethical issues, are more likely to refrain from supporting fraud and thus report wrongdoing. Hence, our study provides evidence that judgments made by individuals concerning the ethics or morality of specific actions are aligned with the individual's actual ethical behavior. In summary, the findings about the relationship between personality and behavior can be regarded as encouraging evidence that individual-level factors are associated with organizational behavior and that the corresponding assessment via questionnaires constitutes a valid tool for screening individuals with tendencies towards reporting observed misconducts. However, these results must be viewed in light of the study's limitations. Since the time available for measuring the personality characteristics after the experiment was sharply limited, we decided to use a greatly reduced set of questions. To gain a thorough understanding about the individual antecedents of whistleblowing, longer versions of personality inventories have to be used to provide a more detailed pattern of personality. Similar to studies which use the HEXACO model in order to predict ethical behavior in general, and studies like Bjørkelo et al. 2010 which use the five-factor model to predict whistleblowing in particular, one could employ the complete HEXACO-60 or the HEXACO-100 inventory to assess more personality factors and their role on whistleblowing behavior. Further, the current study was not able to consider integrity tests and counterproductive work behavior (CWB) (Marcus 2006, Marcus et al. 2007, Ones and Viswesvaran 2001). In general, CWB can be defined as voluntary behavior that violates significant organizational norms, and, in doing so, threatens the wellbeing of the organization, its members, or both (Robinson and Bennett 1995). 
An interesting avenue for future research would be to investigate to which extent individuals, who are categorized to conform to appropriate behaviors in the workplace and in accordance with the legitimate interests of the organization (measured by the degree of CWB), are also more likely to show these behavioral patterns in an experimental context, such as the design we have used, by blowing the whistle when wrongdoing is observed. The findings of these studies might help to resolve the question whether organizations can identify the risk of future unethical incidents and the effectiveness of whistleblowing systems, based on personality assessments. While the strength of experimental approaches as a complement to interviews, surveys and observational data have been highlighted in different economic domains and throughout the whistleblowing research (Kaplan et al. 2009, Hersh 2002, Miceli and Near 1984), it is vital to sound a note of caution regarding issues of external validity. Our randomized experiment was conducted following the standards of experimental economics as a computer-assisted laboratory experiment with students as subjects embedded in an artificial environment for a limited time frame. Although we believe that we have transferred the key features of an actual work environment into the laboratory, discovering fraudulent behavior and its associated feelings in the experiment might be different from those in real organizations. Further, our experimental framework accounts for retaliation by reducing the payoff of the employee after the whistle has been blown. However, psychological costs employees face afterwards in form of mobbing and being treated as a traitor are completely excluded. Another limitation relates to our participants, which were all students and thus a highly selective sample. Although there is evidence that decisions of students over abstract goods in simplified experiments are not necessarily that much different from the target population and their commodities under interest (Remus 1986, Carpenter and Seki 2011, Montmarquette et al. 2004, Bolton et al. 2012), the study should be replicated with a more heterogeneous sample (e.g. managers and employees of different organizations) to reach a more robust conclusion about the prevalence to blow the whistle and the relationship between personality and whistleblowing behavior.

Despite the limitations of our study, our experimental framework offers researchers beyond the use of interviews and surveys a promising approach to studying business ethics in organizations under controlled and incentive-compatible conditions. The first application for our approach addresses the whistleblowing research. Building on the perspective that motivational aspects are intertwined with institutional factors, our experimental framework can be easily adapted to explore how variables related to the whistleblower, in combination with the context in which whistleblowing occurs, affects the likelihood of whistleblowing. One could increase the severity of the wrongdoing, by choosing other third parties who are affected by the manager's 
wrongdoing or increase the amount of money the manager can embezzle, in order to then observe the reaction of the employee. Further, one can examine how the inclination for whistleblowing changes, if the manager himself can decide on how the embezzled money shall be allocated (i.e. offer more money to the employee than currently implemented). Another idea would be to alter the organizational support. In the current study, the manager is charged with certainty, if the employee blows the whistle. However, one could ask how behaviors change, if there was only a probabilistic chance of conviction. This institutional change is interesting for both sides, whether more managers decide to commit fraud and/or whether employees perceive the probability for conviction as too low and therefore remain silent. In this aspect, the locus of control (Rotter 1966) is worth examining, as this personal correlate has been suggested to be an important characteristic for whistleblowing actions (Chiu 2003). ${ }^{10}$ Another discussed whistleblowing policy is to make the employee more liable by sanctioning non-reporting behavior (Tsahuridu and Vandekerckhove 2008). One could investigate how effective this policy would be in promoting more whistleblowing or whether this policy might backfire, since employees might interpret the imposed sanctions as a signal of mistrust and therefore collaborate with the manager against the organization. Yet, future research should further investigate the role of retaliation. In our current design, we included retaliation on the employee by reducing the monetary payoffs in all subsequent periods after the whistle has been blown. However, one could think of re-matching the employee with another manager so that they both work on a joint task, requiring a high-level of mutual trust. In this setting, it would be interesting to examine whether performance suffers due to the employee's reporting record. Especially in light of the False-Claims-Act, which entitles the whistleblower up to 30 percent of the amount the government recovers from the case, receiving a bonus for reporting wrongdoing might give employees in future organizational interactions a harder time, as the motives for whistleblowing can no longer be strictly separated into honesty or purely monetary concerns.

The second application for our approach centers on different institutions for fraud prevention and detection. Even though this is not the essence of this study, the manager's organizational behavior is predestined for future research. According to the fraud triangle by Cressey (Cressey 1973), there are three important factors with regard to committing fraud: opportunity, pressure and rationalization. As opportunity for fraud generally occurs through weaknesses in internal controls, one could examine how different risk management strategies, such as audits and

\footnotetext{
${ }^{10}$ In our experimental setup, the conviction of the manager is completely dependent on the employee's actions, so that the employee has total control over the situation. Therefore, we did not include questions regarding locus of control in our post-experiment questionnaire.
} 
sanctions, have to be structured and aligned so that fraudulent managers perceive a substantial threat of being detected. Apart from deterrence strategies, our experimental framework offers the possibility of studying rationalizations towards fraud. In this part of the fraud triangle, offenders admit the wrongdoing, yet deny that it was wrong, allowing them to maintain a nondeviant self-image whilst continuing to engage in criminal activities (Dellaportas 2013). The use of value-based strategies, such as tailored ethical codes as part of the corporate culture, employee awareness of ethical issues that arise at work are potential candidates to be examined that make the process of self-deception towards fraud as difficult as possible. Additionally, the interplay between the deterrence-based and value-based strategies can be studied within the same framework, thus providing further insights of what works and what hurts in compliance and ethics management.

Following the corporate scandals and the passage of the U.S. Sarbanes-Oxley Act in 2002, organizations are increasingly aware of the importance of business ethics and ethical practices (Vadera et al. 2009, Deloitte 2015). However, simply implementing an ethics and compliance program in an organization may not be sufficient in preventing and detecting corporate fraud and encouraging employees to report unethical practices. Our experimental framework serves as a first step for a comprehensive integration of research on fraud and whistleblowing. Beyond the implications for any particular industry, we believe that researchers studying determinants of ethical decision-making within organizational contexts will find this approach useful in generating new empirical regularities to be addressed by the theory of organizational behavior and in testing mechanisms which help to guard the organization against the hazards of fraudulent behaviors. Particularly, the effectiveness of these mechanisms can be examined in detail and tailored before being implemented, thus avoiding a costly trial-and-error approach organizations are currently confronted with. 


\section{Appendix}

\section{A. Screenshot of the Team Task}

Figure A1: Counting Team Task - Manager View

\begin{tabular}{|c|c|c|}
\hline $\begin{array}{l}\text { Pencost } \\
\qquad \text { won } 16\end{array}$ & & \\
\hline \multicolumn{3}{|c|}{ Bitte zăhlen Sle die Anzahl der 7er in den belden angezeigten Zahlenblocken. } \\
\hline & $\begin{array}{l}\text { Dieser Zahlenblock } \\
\text { wird gerade } \\
\text { von Ihrem } \\
\text { Mitarbeiter } \\
\text { gezählt }\end{array}$ & $\begin{array}{l}120681237165474 \\
474752817485680 \\
828835613431106 \\
552363655157143 \\
314235461328213 \\
540825663770081 \\
502683645421227 \\
874236305665075\end{array}$ \\
\hline & $\begin{array}{l}577316816446623 \\
285300470657771 \\
566233537166131 \\
522500512812323 \\
747700058455336 \\
684248631835522 \\
248758286867360 \\
188801368606476\end{array}$ & $\begin{array}{l}\text { Dieser Zahlenblock } \\
\text { wird gerade } \\
\text { von Ihrem } \\
\text { Mitarbeiter } \\
\text { gezählt }\end{array}$ \\
\hline \multicolumn{3}{|c|}{ Gesamtanzahl der 7er in den beiden angezeigten Zahlenblöcken: } \\
\hline & & \\
\hline
\end{tabular}

Figure A2: Counting Team Task - Employee View

\begin{tabular}{|c|c|c|}
\hline Periose & & \\
\hline \multicolumn{3}{|c|}{ Bitte zählen Sle die Anzahl der 7er in den beiden angezeigten Zahlenblöcken. } \\
\hline & $\begin{array}{l}518381280784473 \\
150425876024888 \\
282008373830813 \\
360180778371532 \\
335757804043207 \\
378726031843167 \\
672240026748328 \\
281383382455828\end{array}$ & $\begin{array}{l}\text { Dieser Zahlenblock } \\
\text { wird gerade } \\
\text { von Ihrem } \\
\text { Abteilungsleiter } \\
\text { gezählt }\end{array}$ \\
\hline & $\begin{array}{l}\text { Dieser Zahlenblock } \\
\text { wird gerade } \\
\text { von Ihrem } \\
\text { Abteilungsleiter } \\
\text { gezählt }\end{array}$ & $\begin{array}{l}756233582570713 \\
158241820414140 \\
137841765435546 \\
675387768403346 \\
351658588540806 \\
687287436783301 \\
707011182458482 \\
774470164841837\end{array}$ \\
\hline \multicolumn{3}{|c|}{ Gesamtanzahl der 7ern in den beiden angezeigten Zahlenblocken: $\square$} \\
\hline
\end{tabular}




\section{B. Instructions of the experiment (translated from German)}

\section{General Information:}

- In the experiment all amounts will be expressed in the fictitious currency „Taler“.

- Apart from the computer mouse and keyboard, no other devices are allowed in the experiment.

- In total, the experiment consists of $\mathbf{1 6}$ periods.

- In the experiment two participants play together as one group.

- Which player belongs to your group will be drawn randomly. The members of a group remain anonymous. You will never get to know who is part of your group.

- At the end of the experiment you will be asked to answer a couple of questions. Complete and sincere answers are very important for the subsequent analysis. The answers are anonymous and will only be used for scientific purposes. Your responses on these questions do not have any influence on your payoff in the experiment.

\section{Information on the Course of the Experiment:}

- Imagine that you are working in a division of a large company. The headquarters of the company is located in Germany, but the branch of your division is in South Africa, where you are responsible for commodity trade. The division consists of exactly two members, a division manager and subordinate employee.

- Whether you are the division manager or the employee, is determined by an estimation problem. First, a glass jar containing marbles is shown to you. After that you must enter your estimation of the amount of marbles in the glass jar on the computer. After making your entry, the correct answer is displayed on your computer screen.

- If you belong to the $50 \%$ of the participants whose estimation is the closest to the correct answer, the role “division manager” will be assigned to you.

- If you do not belong to the $50 \%$ of the participants whose estimation is the closest to the correct answer, the role "employee” will be assigned to you.

- In the case of a tie, the computer program will assign a role to the participants with the same estimation by chance. 
- The role which is assigned to you will remain anonymous and will only be shown to you on the computer screen. During the entire experiment you will remain in the role initially assigned to you.

- Together with the other member of the division you have to solve a division task (see screenshot), for which your division is paid. The remuneration is therefore a team achievement.

- Your division task is to count how often the number 7 occurs in four displayed blocks of numbers. The task is completed as a team with your division member, whereby each team member focuses on exactly two blocks of numbers. Subsequently, you enter your result in the input field and click OK.

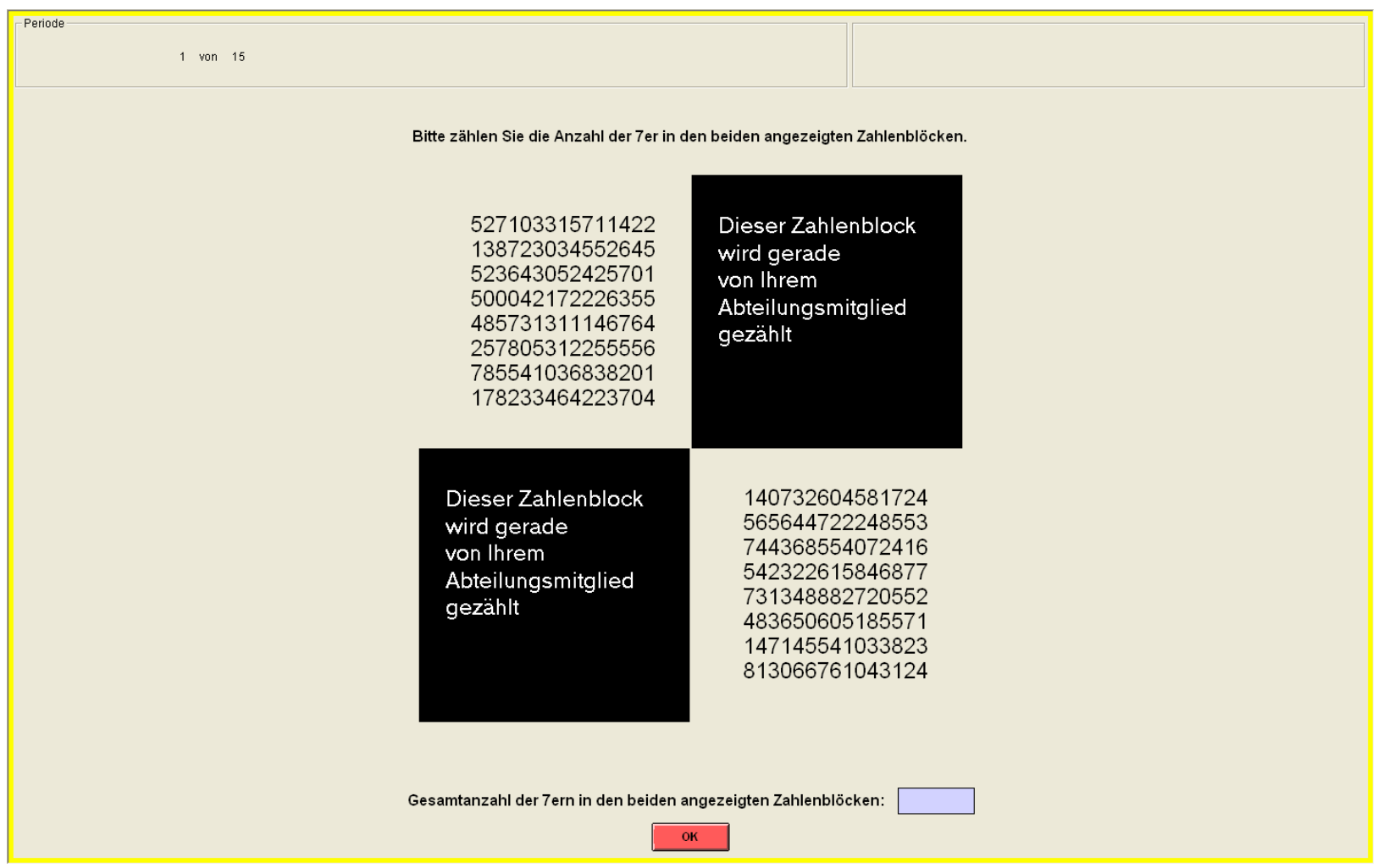

- For counting the two blocks of numbers, the time needed is not limited. After you and your division member have each counted the number $7 \mathrm{~s}$ in the two blocks of numbers assigned to each of you, the total result of your division will be computed.

- You have completed the task successfully, if

o the total amount of number $7 \mathrm{~s}$ counted by your division as a team does not divert from the actual amount by more than four number $7 \mathrm{~s}$ upwards or downwards. As a remuneration, your division receives 10 Taler. The 10 Taler will be divided 
between the division members as follows: If you are in the role of the division manager, you will receive 6 Taler. If the role of the employee was assigned to you, you will receive 4 Taler.

- You have not completed the task as a division, if

0 the total amount of number $7 \mathrm{~s}$ counted by your division as a team diverts from the actual amount by more than four number $7 \mathrm{~s}$ upwards or downwards. In this case your division receives no remuneration in that period.

- Overall, you solve one joint task of this type per period.

- After 5 periods, during which your division has worked together in South Africa, your company in Germany decides to provide an additional budget of 10 Taler per period and donate this budget to an aid project in South Africa as charity. The donation budget is provided by the company for every period anew and irrespective of whether the task has been solved by the division successfully or not. Your division does not have to contribute to the collection of the donation, thus your remuneration is not affected negatively by the donation.

- The aid project, which will receive the donation, is real. It is a project of the organisation GoAhead!, in the course of which a learning centre for HIV-infected orphans in KwaZuluNatal (South Africa) is being established. For further information, refer to the information leaflet, which you received in addition to the instructions.

- As your company in Germany is not able to manage and control the budget for the donation in South Africa due to the geographical distance, it is the division manager's responsibility to decide over the use of additional 10 Taler in all subsequent periods.

\section{Role of the Division Manager:}

- If you take on the role of the division manager, you can decide how you want to proceed with the additional 10 Taler. You have the possibility of either donating the 10 Taler as a real donation to the Organisation GoAhead! or not forwarding the money and instead keeping it in your division. If you, as the division manager, decide to forward the additional 10 Taler in one period, you can decide on the use of the 10 Taler anew in the next period. Thus, you can decide anew in each subsequent period if you want to forward the 10 Taler as a donation or not. If you, as the division manager, decide to not forward the 10 Taler as a donation and instead to keep it in your division, this decision will apply for this period as 
well as for all the subsequent periods. Therefore, you cannot decide on the use of the additional 10 Taler anew, instead you determine with this decision that in this as well as in all subsequent periods the additional 10 Taler will not be forwarded and thus remain in your division.

- Your decision concerning the use of the donation budget is anonymous and no one outside of your division will find out about your decision. Merely, the other member of your division will receive the information concerning your decision on his computer screen.

- If you decide to donate the additional 10 Taler, funded by the company, to GoAhead!, the money will be donated. At the end of the experiment, you can verify the amount of money donated throughout the entire number of periods. It is guaranteed that the donation will be actually made to GoAhead!.

- If you decide to keep the donation within your division, the donation budget of 10 additional Taler will be added to the regular division's remuneration from the task of counting in this as well as in all subsequent periods. Specifically this means, that the 10 additional Taler as well as the remuneration from the division task will be divided between you and your employee, meaning you, as the division manager, receive 6 additional Taler and your employee receives 4 additional Taler. In the case of successfully completing the division task and keeping the donation budget, your period's payoff increases to 12 Taler and your employee's increases to 8 Taler. If you decide to keep the donation budget, this will apply to this and to all subsequent periods as well. Thus, with your decision you determine that the donation budget will remain in your division in this as well as in all subsequent periods.

\section{Role of the Employee}

- If the division manager should decide to keep the donation budget within the division from a certain period onwards, you, in the role of the employee, have the choice of accepting his decision tacitly or reporting it to your company in Germany.

- If you accept the decision of the division manager tacitly, the additional 10 Taler from the donation budget will be divided between you and the division manager as described above and the next period of the experiment will begin.

- If you report the division manager's decision of keeping the donation, the company will demand back the donation budget for the period in which this was reported. Your company 
will ensure that GoAhead! receives the donation by another means in this and in all subsequent periods. Furthermore, your division will be dissolved and you will be transferred to another position. In this position you no longer solve the task of counting as a team, but instead individually on your own. The task of counting is completed successfully, if the total amount of number $7 \mathrm{~s}$ counted by you individually does not divert from the actual amount by more than two number 7s upwards or downwards. For successfully completing the task individually in the role of the division manager you receive 5 Taler and in the role of the employee 3 Taler.

- The experiment ends after a total of 16 periods.

\section{Information on your payoff:}

- At the end of the experiment you will receive a show-up fee of EUR 2.50 and your payoff that you have collected over the 16 periods according to the following exchange rate: EUR 1 per 8 Taler.

- The total donation amount to GoAhead! will be transferred as a single sum in EUR per bank transfer to the account of GoAhead! (bank account number 6662412, sort code (BLZ) 69490000). After the experiment, one participant will be drawn randomly in order to sign the complete donation sum. Besides, the transfer amount will be double-checked by Prof. Fahr.

- The bank transfer confirmation and the confirmation of Prof. Fahr's verification can be found on the homepage of the BaER-Lab one week after the experiment. Thus, you receive the guarantee that the money was actually donated to GoAhead! and is being used for supporting the learning centre in KwaZulu-Natal.

- Apart from the instructions, you receive a slip of paper with further information on GoAhead! and the charity project as well as the internet addresses of GoAhead! and the BaER-Lab Homepage.

\section{Please note the following:}

- During the whole experiment no communication is permitted.

- Mobile phones must be switched off during the complete length of the experiment. 
- Should you have any questions, please remain seated and raise your hand. A supervisor will come over to where you are sitting and answer your question in private.

- All decisions in the experiment are anonymous. Nobody will learn about your identity or your decisions during the experiment.

- The payout also takes place anonymously. Nobody will learn about the payoff of another participant.

- Please remain seated until the payoff time. You will be called by your seat number.

\section{Good luck and thank you for the participation in our experiment!}

GoAhead! is a non-profit organisation, founded and managed by students from Germany. Students in Paderborn have also come together and have founded such an university group. The learning centre in KwaZulu-Natal (South Africa) is an initiative of GoAhead!. The learning centre provides HIV-infected orphans with a safe learning environment and warm meals. Additionally, the children are offered workshops and sports activity, and receive psychological support.

For further information about GoAhead!, the aid project and the donation account, please visit:

http://www.goahead-organisation.de.

http://www.goahead-organisation.de/content/helfen/sk/

spendenkonto/index_ger.html

A confirmation of the donation, can be found a week after the experiment on the following website:

http://www.baer-lab.org
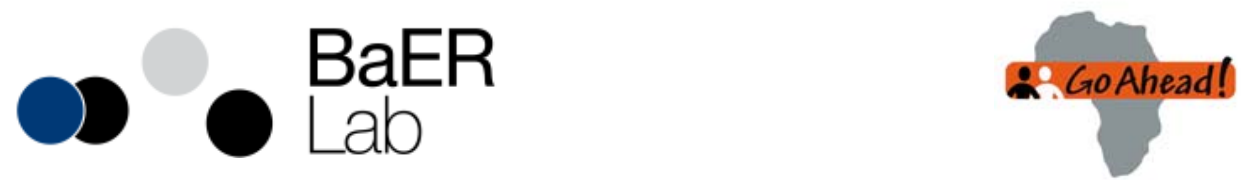


\section{Items used in the post-experiment questionnaire: Selected items of the HEXACO-60 and the HEXACO-100 Personality Inventory-Revised to measure the Honesty-Humility and Altruism facets, and selected items of the DOSPERT Ethical scale.}

Table C1: Selected items of the HEXACO-60 and the HEXACO-PI-R inventory (Source: Ashton and Lee 2009)

\begin{tabular}{|c|c|c|}
\hline & German & English \\
\hline \multicolumn{3}{|l|}{ Honesty-Humility } \\
\hline \multirow[t]{3}{*}{ Fairness } & $\begin{array}{l}\text { Wenn ich wüsste, dass ich niemals } \\
\text { erwischt werde, wäre ich bereit, eine } \\
\text { Million zu stehlen. }\end{array}$ & $\begin{array}{l}\text { If I knew that I could never get caught, I } \\
\text { would be willing to steal a million dollars. }\end{array}$ \\
\hline & $\begin{array}{l}\text { Ich würde niemals Bestechungsgeld } \\
\text { annehmen, auch wenn es sehr viel } \\
\text { wäre. }\end{array}$ & $\begin{array}{l}\text { I would never accept a bribe, even if it were } \\
\text { very large. }\end{array}$ \\
\hline & $\begin{array}{l}\text { Ich würde in die Versuchung geraten, } \\
\text { Falschgeld zu benutzen, wenn ich } \\
\text { sicher sein könnte, damit } \\
\text { durchzukommen. }\end{array}$ & $\begin{array}{l}\text { I'd be tempted to use counterfeit money, if } \\
\text { I were sure I could get away with it. }\end{array}$ \\
\hline \multirow[t]{2}{*}{ Greed } & $\begin{array}{l}\text { Viel Geld zu haben ist nicht besonders } \\
\text { wichtig für mich. }\end{array}$ & $\begin{array}{l}\text { Having a lot of money is not especially } \\
\text { important to me. }\end{array}$ \\
\hline & $\begin{array}{l}\text { Es würde mir viel Freude bereiten, } \\
\text { teure Luxusgüter zu besitzen. }\end{array}$ & $\begin{array}{l}\text { I would get a lot of pleasure from owning } \\
\text { expensive luxury goods. }\end{array}$ \\
\hline \multirow[t]{3}{*}{ Sincerity } & $\begin{array}{l}\text { Ich würde keine Schmeicheleien } \\
\text { benutzen, um eine Gehaltserhöhung zu } \\
\text { bekommen oder befördert zu werden, } \\
\text { auch wenn ich wüsste, dass es } \\
\text { erfolgreich wäre. }\end{array}$ & $\begin{array}{l}\text { I wouldn't use flattery to get a raise or } \\
\text { promotion at work, even if I thought it } \\
\text { would succeed. }\end{array}$ \\
\hline & $\begin{array}{l}\text { Wenn ich von jemandem etwas will, } \\
\text { lache ich auch noch über dessen } \\
\text { schlechteste Witze. }\end{array}$ & $\begin{array}{l}\text { If I want something from someone, I will } \\
\text { laugh at that person's worst jokes. }\end{array}$ \\
\hline & $\begin{array}{l}\text { Ich würde nicht vortäuschen, jemanden } \\
\text { zu mögen, nur um diese Person dazu } \\
\text { zu bringen, mir Gefälligkeiten zu } \\
\text { erweisen. }\end{array}$ & $\begin{array}{l}\text { I wouldn't pretend to like someone just to } \\
\text { get that person to do favors for me. }\end{array}$ \\
\hline \multirow[t]{4}{*}{ Altruism } & $\begin{array}{l}\text { Ich habe Mitgefühl mit Menschen, die } \\
\text { weniger Glück haben als ich. }\end{array}$ & $\begin{array}{l}\text { I have sympathy for people who are less } \\
\text { fortunate than I am. }\end{array}$ \\
\hline & $\begin{array}{l}\text { Ich versuche, Notleidende großzügig } \\
\text { zu unterstützen. }\end{array}$ & I try to give generously to those in need. \\
\hline & $\begin{array}{l}\text { Es würde nicht mich nicht stören, } \\
\text { jemandem zu schaden, den ich nicht } \\
\text { mag. }\end{array}$ & $\begin{array}{l}\text { It wouldn't bother me to harm someone I } \\
\text { didn't like. }\end{array}$ \\
\hline & $\begin{array}{l}\text { Man hält mich für einen hartherzigen } \\
\text { Menschen. }\end{array}$ & People see me as a hard-hearted person. \\
\hline
\end{tabular}




\begin{tabular}{|l|l|}
\hline German & English \\
\hline $\begin{array}{l}\text { 1) Ich würde einen bedeutenden Betrag vom } \\
\text { Einkommen nicht in der Steuererklärung } \\
\text { angeben. }\end{array}$ & $\begin{array}{l}\text { 1) Taking some questionable deductions on } \\
\text { your income tax return. }\end{array}$ \\
$\begin{array}{l}\text { 2) Ich würde eine Affäre mit einem } \\
\text { verheirateten Mann oder einer verheirateten } \\
\text { Frau haben. }\end{array}$ & $\begin{array}{l}\text { 2) Having an affair with a married } \\
\text { man/woman. }\end{array}$ \\
$\begin{array}{l}\text { 3) Ich würde die Arbeit von jemand anderem } \\
\text { als die eigene ausgeben. }\end{array}$ & $\begin{array}{l}\text { 3) Passing off somebody else's work as your } \\
\text { own. }\end{array}$ \\
$\begin{array}{l}\text { 4) Ich würde ein Geheimnis meines Freundes } \\
\text { jemand anderem verraten. }\end{array}$ & $\begin{array}{l}\text { 4) Revealing a friend's secret to someone } \\
\text { else. }\end{array}$ \\
$\begin{array}{l}\text { 5) Ich würde meine kleinen Kinder für eine } \\
\text { Besorgung allein zu Hause lassen. }\end{array}$ & $\begin{array}{l}\text { 5) Leaving your young children alone at home } \\
\text { while running an errand. }\end{array}$ \\
6) Ich würde eine gefundene Geldbörse mit & $\begin{array}{l}\text { 6) Not returning a wallet you found that } \\
\text { contains \$200. }\end{array}$ \\
\hline
\end{tabular}

\section{References}

Abbink, K., H. Hennig-Schmidt. 2006. Neutral versus loaded instructions in a bribery experiment. Experimental Economics 9(2) 103-121.

Abbink, K., B. Irlenbusch, E. Renner. 2002. An experimental bribery game. Journal of Law, Economics, and Organization 18(2) 428-454.

Abeler, J., A. Becker, A. Falk. 2014. Representative evidence on lying costs. Journal of Public Economics 113 96-104.

Andreoni, J., J. Miller. 2002. Giving according to GARP: An experimental test of the consistency of preferences for altruism. Econometrica 70(2) 737-753.

Apesteguia, J., M. Dufwenberg, R. Selten. 2007. Blowing the whistle. Economic Theory 31(1) $143-166$.

Arkes, H. R., C. A. Joyner, M. V. Pezzo, J. G. Nash, K. Siegel-Jacobs, E. Stone. 1994. The psychology of windfall gains. Organizational Behavior and Human Decision Processes 59(3) 331-347. 
Ashton, M. C., K. Lee. 2007. Empirical, theoretical, and practical advantages of the HEXACO model of personality structure. Personality and Social Psychology Review 11(2) 150-166.

Ashton, M. C., K. Lee. 2008a. The HEXACO model of personality structure and the importance of the H factor. Social and Personality Psychology Compass 2(5) 19521962.

Ashton, M. C., K. Lee. 2008b. The prediction of Honesty-Humility-related criteria by the HEXACO and Five-Factor Models of personality. Journal of Research in Personality 42(5) 1216-1228.

Ashton, M. C., K. Lee. 2009. The HEXACO-60: A short measure of the major dimensions of personality. Journal of Personality Assessment 91(4) 340-345.

Ashton, M. C., K. Lee, R. E. de Vries. 2014. The HEXACO Honesty-Humility, Agreeableness, and Emotionality factors: A review of research and theory. Personality and Social Psychology Review 18(2) 139-152.

Association of Certified Fraud Examiners. 2014. Report to the nations on occupational fraud and abuse: 2014 Global fraud study, http:/www.acfe.com/rttn/docs/2014-report-tonations.pdf. Retrieved March 31, 2016.

Barr, A., D. Serra. 2009. The effects of externalities and framing on bribery in a petty corruption experiment. Experimental Economics 12(4) 488-503.

Bigoni, M., S.-O. Fridolfsson, C. Le Coq, G. Spagnolo. 2008. Fines, leniency, rewards and organized crime: Evidence from antitrust experiments. SSE/EFI Working Paper Series in Economics and Finance 698, Stockholm School of Economics.

Bjørkelo, B., S. Einarsen, S. B. Matthiesen. 2010. Predicting proactive behaviour at work: Exploring the role of personality as an antecedent of whistleblowing behaviour. Journal of Occupational and Organizational Psychology 83(2) 371-394.

Bolton, G. E., A. Ockenfels. 2000. ERC: A theory of equity, reciprocity, and competition. American Economic Review 90(1) 166-193.

Bolton, G. E., A. Ockenfels, U. W. Thonemann. 2012. Managers and students as newsvendors. Management Science 58(12) 2225-2233. 
Boylan, S. J., G. B. Sprinkle. 2001. Experimental evidence on the relation between tax rates and compliance: The effect of earned vs. endowed income. Journal of the American Taxation Association 23(1) 75-90.

Brief, A. P., S. J. Motowidlo. 1986. Prosocial organizational behaviors. Academy of Management Review 11(4) 710-725.

Carpenter, J., E. Seki. 2011. Do social preferences increase productivity? Field experimental evidence from fisherman in Toyama Bay. Economic Inquiry 49(2) 612-630.

Cassematis, P. G., R. Wortley. 2013. Prediction of whistleblowing or non-reporting observation: The role of personal and situational factors. Journal of Business Ethics 117(3) 615-634.

Cherry, T. L., P. Frykblom, J. F. Shogren. 2002. Hardnose the dictator. American Economic Review 92(4) 1218-1221.

Chiu, R. K. 2003. Ethical judgment and whistleblowing intention: Examining the moderating role of locus of control. Journal of Business Ethics 43(1) 65-74.

Cohn, A., E. Fehr, M. A. Maréchal. 2014. Business culture and dishonesty in the banking industry. Nature $51686-89$.

Costa, P. T., R. R. McCrae. 1995. Domains and facets: Hierarchical personality assessment using the revised NEO personality inventory. Journal of Personality Assessment 64(1) $21-50$.

Cressey, D. R. 1973. Other people's money: A study in the social psychology of embezzlement. Patterson Smith, Monclair, NJ.

Dasgupta, S., A. Kesharwani. 2010. Whistleblowing: A Survey of Literature. IUP Journal of Corporate Governance 9(4).

Davis, D. D., C. A. Holt. 1993. Experimental economics. Princeton University Press, Princeton, New Jersey.

Davis, M. 1996. Some paradoxes of whistleblowing. Business \& Professional Ethics Journal 15(1) 3-19.

De George, R. T. 2010. Business ethics, 7th ed. Prentice Hall, New York.

Dellaportas, S. 2013. Conversations with inmate accountants: Motivation, opportunity and the fraud triangle. Accounting Forum 37(1) 29-39. 
Deloitte. 2015. In focus: 2015 compliance trends survey, Deloitte.

Dozier, J. B., M. P. Miceli. 1985. Potential predictors of whistle-blowing: A prosocial behavior perspective. Academy of Management Review 10(4) 823-836.

Dworkin, T. M., M. S. Baucus. 1998. Internal vs. external whistleblowers: A comparison of whistleblowering processes. Journal of Business Ethics 17(12) 1281-1298.

Dyck, A., A. Morse, L. Zingales. 2010. Who blows the whistle on corporate fraud? The Journal of Finance 65(6) 2213-2253.

Eckel, C. C., P. J. Grossman. 1996. Altruism in anonymous dictator games. Games and Economic Behavior 16(2) 181-191.

Fehr, E., U. Fischbacher. 2004. Third-party punishment and social norms. Evolution and Human Behavior 25(2) 63-87.

Fehr, E., U. Fischbacher, S. Gächter. 2002. Strong reciprocity, human cooperation, and the enforcement of social norms. Human Nature 13(1) 1-25.

Fehr, E., S. Gächter. 2002. Altruistic punishment in humans. Nature 415 137-140.

Fehr, E., K. M. Schmidt. 1999. A theory of fairness, competition, and cooperation. Quarterly Journal of Economics 114(3) 817-868.

Fischbacher, U. 2007. z-Tree: Zurich toolbox for ready-made economic experiments. Experimental Economics 10(2) 171-178.

Fischbacher, U., F. Föllmi-Heusi. 2013. Lies in disguise: An experimental study on cheating. Journal of the European Economic Association 11(3) 525-547.

Gill, D., V. Prowse. 2012. A Structural Analysis of Disappointment Aversion in a Real Effort Competition. American Economic Review 102(1) 469-503.

Gino, F., S. Ayal, D. Ariely. 2009. Contagion and differentiation in unethical behavior: The Effect of One Bad Apple on the Barrel. Psychological Science 20(3) 393-398.

Gino, F., E. L. Krupka, R. A. Weber. 2013. License to cheat: Voluntary regulation and ethical behavior. Management Science 59(10) 2187-2203.

Gneezy, U. 2005. Deception: The role of consequences. The American Economic Review 95(1) 384-394. 
Greiner, B. 2015. Subject pool recruitment procedures: Organizing experiments with ORSEE. Journal of the Economic Science Association 1(1) 114-125.

Hersh, M. A. 2002. Whistleblowers - Heroes or traitors?: Individual and collective responsibility for ethical behaviour. Annual Reviews in Control 26(2) 243-262.

Heyes, A., S. Kapur. 2009. An economic model of whistleblower policy. Journal of Law, Economics, and Organization 25(1) 157-182.

Hinloopen, J., A. R. Soetevent. 2008. Laboratory evidence on the effectiveness of corporate leniency programs. The RAND Journal of Economics 39(2) 607-616.

Hoffman, W. M., R. E. McNulty. 2011. A business ethics theory of whistleblowing:

Responding to the $\$ 1$ trillion question. M. Arszulowicz, W. W. Gasparski, eds. Whistleblowing: In defense of proper action. Transaction Publishers, New Brunswick, USA, 45-59.

Hoffman, W. M., M. S. Schwartz. 2015. The morality of whistleblowing: A commentary on Richard T. De George. Journal of Business Ethics 127(4) 771-781.

Jos, P. H., M. E. Tompkins, S. W. Hays. 1989. In praise of difficult people: A portrait of the committed whistleblower. Public Administration Review 49(6) 552-561.

Jubb, P. B. 1999. Whistleblowing: A restrictive definition and interpretation. Journal of Business Ethics 21(1) 77-94.

Kaplan, S., K. Pany, J. Samuels, J. Zhang. 2009. An examination of the association between gender and reporting intentions for fraudulent financial reporting. Journal of Business Ethics 87(1) 15-30.

King, G., III. 1997. The effects of interpersonal closeness and issue seriousness on blowing the whistle. Journal of Business Communication 34(4) 419-436.

Kohlberg, L. 1969. Stage and sequence: The cognitive-developmental approach to socialization. D. A. Goslin, ed. Handbook of socialization theory and research. Rand McNally, Chicago, 347-480.

KPMG. 2007. Profile of a fraudster survey 2007, KPMG, Poland.

Lee, K., M. C. Ashton. 2004. Psychometric properties of the HEXACO personality inventory. Multivariate Behavioral Research 39(2) 329-358. 
Lee, K., M. C. Ashton, R. E. de Vries. 2005. Predicting workplace delinquency and integrity with the HEXACO and five-factor models of personality structure. Human Performance 18(2) 179-197.

Leeds, R. 1963. Altruism and the norm of giving. Merrill-Palmer Quarterly of Behavior and Development 9(3) 229-240.

Levine, D. K. 1998. Modeling altruism and spitefulness in experiments. Review of Economic Dynamics 1(3) 593-622.

Levitt, S. D., J. A. List. 2007. What do laboratory experiments measuring social preferences reveal about the real world? The Journal of Economic Perspectives 21(2) 153-174.

Lindblom, L. 2007. Dissolving the moral dilemma of whistleblowing. Journal of Business Ethics 76(4) 413-426.

Marcus, B. 2006. Inventar berufsbezogener Einstellungen und Selbsteinschätzungen (IBES). Hogrefe, Göttingen.

Marcus, B., K. Lee, M. C. Ashton. 2007. Personality dimensions explaining relationships between integrity tests and counterproductive behavior: Big Five, or one in addition? Personnel Psychology 60 1-34.

Mazar, N., O. Amir, D. Ariely. 2008. The dishonesty of honest people: A theory of selfconcept maintenance. Journal of Marketing Research 45(6) 633-644.

McCrae, R. R., P. T. Costa. 1987. Validation of the Five-Factor model of personality across instruments and observers. Journal of Personality and Social Psychology 52(1) 81-90.

Mesmer-Magnus, J. R., C. Viswesvaran. 2005. Whistleblowing in organizations: An examination of correlates of whistleblowing intentions, actions, and retaliation. Journal of Business Ethics 62(3) 277-297.

Miceli, M. P., J. B. Dozier, J. P. Near. 1991. Blowing the whistle on data fudging: A controlled field experiment. Journal of Applied Social Psychology 21(4) 271-295.

Miceli, M. P., J. P. Near. 1984. The relationships among beliefs, organizational position, and whistle-blowing status: A discriminant analysis. Academy of Management Journal 27(4) $687-705$.

Miceli, M. P., J. P. Near. 1992. Blowing the whistle: The organizational and legal implications for companies and employees. Lexington Books, New York. 
Miceli, M. P., J. P. Near. 2002. What makes whistle-blowers effective? Three field studies. Human Relations 55(4) 455-479.

Miceli, M. P., J. R. Van Scotter, J. P. Near, M. T. Rehg. 2001. Individual differences and whistle-blowing. Academy of Management Proceedings 2001 C1-C6.

Montmarquette, C., J.-L. Rullière, M.-C. Villeval, R. Zeiliger. 2004. Redesigning teams and incentives in a merger: An experiment with managers and students. Management Science 50(10) 1379-1389.

Near, J. P., M. S. Baucus, M. P. Miceli. 1993. The relationship between values and practice: Organizational climates for wrongdoing. Administration \& Society 25(2) 204-226.

Near, J. P., M. P. Miceli. 1985. Organizational dissidence: The case of whistle-blowing. Journal of Business Ethics 4(1) 1-16.

Near, J. P., M. P. Miceli. 1996. Whistle-blowing: Myth and reality. Journal of Management 22(3) 507-526.

Norman, W. T. 1963. Toward an adequate taxonomy of personality attributes: Replicated factor structure in peer nomination personality ratings. Journal of Abnormal and Social Psychology 66(6) 574-583.

Oh, L.-B., H.-H. Teo. 2010. To blow or not to blow: An experimental study on the intention to whistleblow on software piracy. Journal of Organizational Computing and Electronic Commerce 20(4) 347-369.

Ones, D. S., C. Viswesvaran. 2001. Integrity tests and other criterion-focused occupational personality scales (COPS) used in personnel selection. International Journal of Selection and Assessment 9(1/2) 31-39.

PricewaterhouseCoopers. 2012. Fighting economic crime in the financial services sector, PricewaterhouseCoopers.

Remus, W. 1986. Graduate students as surrogates for managers in experiments on business decision making. Journal of Business Research 14(1) 19-25.

Reuben, E., M. Stephenson. 2013. Nobody likes a rat: On the willingness to report lies and the consequences thereof. Journal of Economic Behavior \& Organization 93 384-391.

Robinson, S. L., R. J. Bennett. 1995. A typology of deviant workplace behaviors: A multidimensional scaling study. Academy of Management Journal 38(2) 555-572. 
Rolison, J. J., Y. Hanoch, M. Gummerum. 2013. Characteristics of offenders: The HEXACO model of personality as a framework for studying offenders' personality. The Journal of Forensic Psychiatry \& Psychology 24(1) 71-82.

Rothschild, J., T. D. Miethe. 1999. Whistle-blower disclosures and management retaliation: The battle to control information about organization corruption. Work and Occupations 26(1) $107-128$.

Rotter, J. B. 1966. Generalized expectancies for internal versus external control of reinforcement. Psychological Monographs: General and Applied 80(1) 1-28.

Serra, D., L. Wantchekon, eds. 2012. New advances in experimental research on corruption. Emerald, United Kingdom.

Sims, R. L., J. P. Keenan. 1998. Predictors of external whistleblowing: Organizational and intrapersonal variables. Journal of Business Ethics 17(4) 411-421.

Transparency International. 2010. Whistleblowing: An effective tool in the fight against corruption. Policy Position, Transparency International, Berlin.

Tsahuridu, E. E., W. Vandekerckhove. 2008. Organisational whistleblowing policies: Making employees responsible or liable? Journal of Business Ethics 82(1) 107-118.

Vadera, A. K., R. V. Aguilera, B. B. Caza. 2009. Making sense of whistle-blowing's antecedents: Learning from research on identity and ethics programs. Business Ethics Quarterly 19(4) 553-586.

Weber, E. U., A. Blais, N. E. Betz. 2002. A domain specific risk attitude scale: Measuring risk perceptions and risk behaviors. Journal of Behavioral Decision Making 15(4) 263290.

Zettler, I., B. E. Hilbig. 2010. Honesty-Humility and a person-situation interaction at work. European Journal of Personality 24(7) 569-582. 